\title{
LAW AND THE MAKING OF SLAVERY IN COLONIAL VIRGINIA
}

\section{Ashton Wesley Welch \\ Department of History \\ Creighton University}

Some authorities from the antebellum period to the present have located the source of the American law of slavery in continental civil law codes and hence in Roman slave law. They have been unable or unwilling to connect the brutal system of institutionalized racial slavery that emerged in Virginia and elsewhere in the American slave kingdom with what they have perceived as an open, freedom-favoring Anglo-American legal system and have thus sought an explanation of its legal underpinnings in other jurisdictical standards. Both the absence of chattel slavery in English law and the common law's claimed bias in favor of liberty have often been cited as reasons why it is impossible that English law could be the source of such an abomination. ${ }^{1}$

The slave law that developed in seventeenth century Virginia fits squarely within the broad English legal tradition, however. The common law represents only one aspect of that tradition, which 


\section{Ethnic Studies Review Volume 27: 1}

also includes equity, ecclesiastical courts, and, most important in this context, the less formal conciliar law used to govern areas on the edge of England, such as Wales, the Marches, and Ireland. Upon study of the early decisions of the Virginia Council sitting as a judicial court, it becomes apparent that the swift, summary justice of these outlying councils was a clear and direct antecedent of the system of justice that sanctioned racial slavery in Virginia. Once the early Virginia Council had helped impose slavery, the maturing legal system could then use the common law as a tool to regulate it.

\section{Slavery and the Law in Virginia before $\mathbf{1 6 7 0}$}

Prior to the 1660s the Virginia legal system oscillated between tacit recognition of the relative equality of Blacks and an avowed declaration of their inferiority. The earliest law of slavery in Virginia served to cut off routes of escape to freedom for a people already enslaved through custom. This law developed in an atmosphere of unconstrained legal authority and in response to compelling economic and cultural circumstances. Its legal underpinnings were firmly rooted in English legal and political traditions. There was no legal declaration that Africans were to be slaves, but rather a series of cases, followed by legislation, that dealt with the practical problems arising from the custom of holding Africans as slaves. ${ }^{2}$ The effect of these laws and decisions was to make it increasingly difficult for Blacks to be anything but slaves. The paths of escape from this condition were gradually narrowed until choked off nearly altogether.

This early Virginian slave law came about to clear up ambiguities in customary practice. Custom and law recognized the existence of property interests in people. Black labor was treated differently from its white counterpart almost from its beginning in Virginia. The legal basis of white service was contract. Ordinarily white laborers had indentures that specified that their labor would be the property of their master for a particular period of time. Most Africans, however, having arrived as involuntary immigrants, were not parties to any contract limiting their term of service nor were their services regulated by the law. Moreover statutory provisions that limited the terms of service for white laborers who arrived in Virginia without indentures were 
not used to similarly protect Africans, who could thus be held for life. ${ }^{3}$ The customary practice of holding black servants for a term of life began the legal process of converting people, who possessed both rights and duties, into chattel property. Not all Africans who entered Virginia in the early 1600 s were held for life. Some enjoyed a measure of freedom. Some were treated as indentured servants and released when their term was over. More gained their freedom through manumission. ${ }^{4}$ The case of Anthony Johnson, a free Black who claimed headrights for Africans he imported himself, illustrates the lack of uniformity in the status of Blacks in the early decades of their presence. ${ }^{5}$ Legal records from the first half of the century reveal instances of Blacks who earned wages and bought land and of black males testifying in trials of white men.

Still, even though there was some degree of fluidity in their status in the early decades, Blacks, without the protection of written contracts or statutory provisions, were uniquely vulnerable. The early case law suggests that their vulnerability was quickly exploited. The legal dehumanization of black Virginians was aided by a series of decisions handed down by the General Court beginning in the 1620 s. These cases make it clear that black labor was treated differently from white, and validate and regulate many of the elements of this customary difference.

The earliest reported cases involving Blacks are quite brief and are not especially revealing about their status or circumstances. This ambiguity can be seen in cases of the mid-1620s. "John Phillip, a Negro Christened in England," testified in the 1624 debt trial of Symon Tuchinge, a white man. Phillip seemingly was permitted to testify because he was a Christian. 6 The following year, 1625, in a case involving a black man named Brase, the court ordered that "the negro yt cam in with Capt Jones" serve Lady Yeardley until further order but granted him what amounted to wages for his service.? The next month the court ordered that this same man, "ye negro called by the name of brase shall belonge to Sr ffrancis Wyatt Gournor \&c., as his servant" despite Captain Jones' alleged sale of him to another man. ${ }^{8}$

By the middle of the seventeenth century, court decisions and statuary acts more clearly indicate a debased status for 


\section{Ethnic Studies Review Volume 27: 1}

Blacks. In 1630, in the case of Re Davis, the court ordered Hugh Davis "to be soundly whipt before an assembly of negroes \& others for abusing himself to the dishon[o]r of God and shame of Christians, by defiling his body in lying with a negro. . .."9 Ten years later, in Re Sweat, the court heard the case of Robert Sweat, a white colonist charged with having impregnated an unnamed black woman. The court ordered Sweat "to do public penance for his offence...getting [the] negroe woman with child" and "the said negro woman...be whipt at the whipping post". The circumstances surrounding the cases of Davis and Sweat are unknown, but the decisions make it quite clear that "negroes" were regarded as separate and inferior. Like Hugh Davis, Sweat "defiled his body" and shamed God by having sexual relations with a lower form of humanity. 10

This impression is reinforced by Act $X$ decreed by the legislature in 1639 that "[a]II persons except negroes to be provided with arms and ammunition to be fined at pleasure of the Governor and the Council."11 This was the first legislative enactment to mention Blacks specifically. The requirement that all Whites, including servants, bear arms while all Blacks, including free men, were forbidden to do so, reveals the continuing evolution of a distinct, and lesser, position for Blacks.

A series of cases in the early 1640 s demonstrate that black labor was not subject to term restrictions. In July 1640, three runaway slaves were caught and tried before the court. All three were whipped, and while the two Whites, a Dutchman and a Scot, had several years added to their indentures, the third, a black man named John Punch, was ordered to serve his "master or his assigns for the time of his natural life here or elsewhere."12 In October of the same year, another group of runaways was caught in a skiff on the Elizabeth River and punished similarly. Emmanuel, the one Black recaptured, received the same harsh punishments meted out to the others, with three exceptions. He alone received no additional years on his term of service, presumably because he was already a servant for life. He was also branded with an " $R$ " on his cheek and was required to wear shackles for a year. ${ }^{13}$

The question of the heritability of enslavement rose concomitantly with the drift in equating blackness with slavery. 
Several cases over the twenty-year period from the 1640s to the 1660 s concern themselves with the hereditary nature of slavery and the effect of white parentage on a Black's slave status. Uncertainty is definitely evident in the early legal record. The 1641 case of John Graweere, for example, clearly suggests his status as a slave but reveals confusion about exactly how that status might be transmitted to children. Graweere was a servant of William Evans, who allowed him to raise hogs provided that Mr. Evans received half of the profit. Graweere fathered a son to a black slave owned by Lieutenant Robert Sheppard. Mr. Graweere purchased his son's freedom from Lt. Sheppard in order to raise him to be a Christian "taught and exercised in the Church of England." After the sale, Evans asserted title to the child. In upholding Graweere's right to his son, the court recognized that Sheppard's claim to the boy lay in the lieutenant's ownership of the mother, but it also ordered that the boy would be free from any claim of Evans and his heirs, whose only possible right to the boy would arise from their ownership of the father. ${ }^{14}$ Early in the next decade, the court rejected a challenge to a 1652 sale, by a Virginia planter of a 10 year old black girl "with her issue and produce duringe her (or either of them) for their Life tyme" and "their Successors forever."15 This is obviously a case where children inherited their slave status from their mother with no thought given to the race or ownership of their father.

The case of Mihill Gowen, who was freed by the will of Christopher Stafford, illustrates another aspect of this issue. In the York County court in 1657 Stafford's sister, Anne Barnhouse, formally renounced any claims to Gowen. She then gave a boy "born of the body of my negro Rosa being baptised" to Gowen. She referred to the boy as Gowen's "Sonne William."16 By making the gift, Ms. Barnhouse clearly acted as if she believed that otherwise she would have had lawful possession of William, and the basis for that must have been that she owned William's mother.

The case of Elizabeth Key, decided in 1656, advances the issue of the effect of white parentage on slave status. Elizabeth was found by the county court to have been the child of a slave woman by a white man, Thomas Key. In fact, shortly after 
Ethnic Studies Review Volume 27: 1

Elizabeth's birth, Mr. Key had been fined "for getting his negro woman with Childe which said Negro was the Mother of the said Molletto." As an adult, when about to be sold as part the estate of Colonel John Mottram, Ms. Key claimed her freedom on the basis of her birth to a free white father. This case went to the Virginia assembly which returned it to the county court for reconsideration because no one appeared before the Burgesses to speak against Key's petition for freedom. Despite the inconclusive result, the assembly's report showed that the Burgesses believed she was entitled to freedom. One possible ground behind their thinking was her acceptance of Christianity. Prevailing legal practices provide another possible explanation: Common Law held that "the Child of a Woman slave begott by a freeman ought to bee free." The end result was that Elizabeth Key was declared free in Northumberland County, and then married the white attorney who had represented her. ${ }^{17}$

The uncertainty about the status of Blacks born from miscegenous relationships was cleared up 1652 by a statute which provided that: "Whereas some doubts have arisen whether children got by an Englishman upon a negro woman should be slave or free ... That all children born in this country shall be held bond or free only according to the condition of the mother . . ."18 Thousands of Blacks, including "Mulattoes," would have been entitled to freedom had the legislature followed the English legal doctrine that the status of the child was determined by the status of the father.

During the same time period, when the question of race and slavery was reaching solution, confusion also surrounded the issue of the effect of Christian baptism on slave status. This was a vexing problem, which presented itself with some frequency, resulting from the pull of two competing notions. Not surprisingly up until 1680, Virginia, and some other English colonies, often followed the English and Spanish custom of extending the privileges of a free person to baptized Blacks.19 For several decades, white Virginians were undecided whether blackness or Christianity was more important on the status of Blacks. Some Africans who had become Christians before arriving in Virginia were accorded a higher status than other Africans. In the same uneven fashion, a few of the Africans who converted after their 
arrival in the colony also gained additional rights. Black Christians were allowed to testify in court and could even bring suit. Other Blacks could not. ${ }^{20}$ The acceptance of Christian baptism was a powerful symbol to white Virginians, who saw it as crucial evidence of the development of civility and rationality. Since these qualities were seen as incompatible with slave status, conversion sometimes brought manumission, or at least some degree of greater personal freedom. As noted, the decision in the case of Elizabeth Key also rests at least in part on her claim that she was entitled to her freedom because she was a Christian. In the 1667 case of Fernando, however, a black man's suit for freedom on the grounds of Christian baptism failed. This lack of clarity produced anxiety and a drive for resolution, reflected in confusion in the judicial decisions, and ultimately, in the passage of a law that resolved the problem. ${ }^{21}$

In the meantime, several court cases concerned with the problem were adjudicated. In 1644, the General Assembly heard the case of Manuel, who was purchased as a "slave for Ever", but later became a Christian and demanded his freedom. The court judged that, as a Christian, Manuel was not a slave, and should "serve as other Christian servants do." Still, it ordered him to serve ten years, a longer term than white Christian servants were required to serve; 22 the sentence reflected the pull of forces that saw all Blacks as slaves. Significantly, immediately after this decision, Manuel's owner sought compensation from the government, strong evidence that there was an expectation that Blacks would be held in perpetual servitude.

Again, statutory law was used to decide the matter once and for all, clearing up any confusion by declaring in 1667 that baptism had no effect on the status of Blacks as slaves. After Fernando initiated his case, but before the court rendered its decision, the Virginia legislature enacted a statute which read in part:

Whereas some doubts have arisen whether children that are slaves by birth, and the charity and pity of their owners made partakers of the blessed sacrament of baptism, should by virtue of their baptism be made free, it is enacted that baptism does not alter the condition of 
Ethnic Studies Review Volume 27: 1

the person as to his bondage of freedom; masters freed from this doubt may carefully propagate Christianity by permitting slaves to be admitted to that sacrament. ${ }^{23}$

In reality through the act, slaveholders were now encouraged to convert their slaves, since they no longer risked any loss of property thereby. The assembly followed its declaration on baptism with a decree that non-Christian servants brought to colony "by shipping" were to be slaves for life. ${ }^{24}$

Hence, although status in the first half of the seventeenth century was not rigidly fixed by race, the effect of the legal decisions and statutory enactments of that period was to make it more likely that Blacks would be treated as slaves, and that once slaves they would remain so. The custom of holding black laborers for a term of life was reflected in, as well as accepted and validated by, early case decisions. Routes of escape from this condition were firmly closed off by legislation in the 1660s. Any doubt that the law recognized slavery by the end of decade could be seen in a 1669 statute, An Act about the casuall killings of slaves:

Whereas the only law in force for the punishment of refractory servants resisting their master, mistress or overseer, cannot be inflicted on negroes [because the punishment was extension of time], Nor the obstinacy of many of them by other than violent meanes supprest. Be it enacted and declared by this grand assembly, if any slave resist his master... and by the extremity of the correction should chance to die, that his death shall not be accompted Felony, but the master (or that other person appointed by the master to punish him) be acquit from molestation, since it cannot be presumed that propensed malice (which alone makes murther Felony) should induce any man to destroy his own estate. ${ }^{25}$

\section{The Cultural and Economic Environment of the Development of Slave Law in Virginia}

The practice of holding Blacks as slaves and the legal decisions 
that gradually institutionalized that custom were connected to cultural and economic conditions that existed in England and in Virginia in the seventeenth century. The widespread availability of free land in Virginia, coupled with the boom in tobacco prices that lasted through the 1620s, fueled an extremely high demand for labor in the colony. Since land that could grow tobacco was abundant, the key to amassing wealth was the acquisition of a stable, and large, supply of labor to work that land.26

As the demand for workers in Virginia rose steadily, planters increasingly turned to indentured servants to fill this demand. These servants arrived in Virginia bound by contracts that exacted long terms of service in exchange for their transportation from England.27 The long periods of required service led to the development of a market in men unlike anything seen in Britain, where labor contracts seldom exceeded a year. Masters in Virginia could freely buy and sell servants at any time for any period of years covered by their contracts, and servants could be sold without their consent. ${ }^{28}$ Servants, without the desire to be rehired or the inclination to be pleasing, had little reason to be productive or conscientious or even respectful. Masters holding little hope or expectation of rehiring their servants for another term alternated between leniency and despotism with their workers, attempting in the former to bribe the hires and in the latter to extract the full measure they believed was their due. The latter became the norm. The Council regularly supported masters' cruelties to their servants. Probably the worst example is the case of Elizabeth Abbott and Elias Hinton, servants of John and Alice Proctor. Both servants died after receiving a series of brutal beatings. A witness testified that Proctor had beaten Hinton with a rake, and after one especially bad beating Abbott ran away to some neighbors who "fownd she had been sore beaten and her body full of sores and holes very dangerously raunkled and putrified both above her wast and uppon her hips and thighs." Still, they returned her to her master, begging his pardon, and he was apparently never punished for either death. Mistreatment was thus common, and although it was constrained to a limited degree by the judiciary, it was generally accepted and even expected. 29

Labor was not the only commodity in short supply. Severe 


\section{Ethnic Studies Review Volume 27: 1}

food shortages were also a major problem for the Virginia Company and its dependents during the 1620s, as cornfields were neglected in favor of tobacco. ${ }^{30}$ Even after the labor shortage was alleviated, population growth coupled with meager increases in the cultivation of food crops kept prices relatively high.

These economic conditions, however, did provide many opportunities for the most powerful men in the colony to enrich themselves. One of the ways they did this was to acquire most of the black workers that arrived in Virginia, which they took great pains to do. Black labor was cheaper and more valuable to the Virginia planters, especially as the costs of white indentured servants also began to rise, simply because Blacks could be kept longer than white servants. ${ }^{31}$ The desire of the leading planters for slaves was strong, even when white labor was neither scarce nor unruly. ${ }^{32}$ The high demand for slaves in the British Caribbean islands, however, left few for Virginia from British suppliers, but some regular trade was established with the Dutch, and some unsuccessful attempts to go directly to Africa were made. ${ }^{33}$ Though only a small number of slaves trickled into Virginia until the Caribbean islands were stocked, the demand for black labor continued to increase in the mainland colony long before then. By 1660, Virginia had enacted a law offering special inducements to Dutch shippers to bring slaves to the colony. 34

Because it was relatively difficult to get slaves and because their purchase required a relatively high initial outlay of capital, slave owners tended to be the wealthiest, most powerful people in the colony. 35 This economic reality can be seen even in the very first account of an arrival of Blacks into Virginia, John Rolfe's 1620 letter to Sir Edwin Sandys, treasurer of the Virginia Company. ${ }^{36}$ These first "20. and odd Negroes" were bartered by the Governor of Virginia, George Yeardley, and a merchant, Abraham Piersey, in exchange for food, at a time of chronic food shortages. By 1625, these two men owned 15 of the 23 Blacks in the colony. ${ }^{37}$ Both also sat on the Virginia General Court.

Demand for labor explains why Blacks were brought to Virginia, but not why they were enslaved, or even why, regardless of their social rank in Africa, they were placed on a lower 
social stratum than that of white servants. Cultural factors, particularly English racial attitudes, help provide this explanation. Here, it can be seen that the underlying reason for the discrimination that took place in seventeenth-century Virginia was the pervasive English prejudice towards Africans that existed before 1619.

The Tudor-Stuart antipathy toward black Africans has been well documented. The evidence is fairly clear that the notion that Africans were fundamentally different from, and inferior to, Europeans arose in sixteenth-century England in response to a number of circumstances. England's insularity before the middle of that century and the English sudden interactions with people quite different from themselves in appearance and culture coupled with their simultaneous discovery of the great apes and the emotional impact of the color black in their culture led to a pervasive belief that black Africans were both biologically and culturally unworthy of being treated as equals. Ignorant of the history of Christianity in Africa, including its survival in Northeastern Africa, Englishmen asserted that Africans were not Christians, and their dark skin was a curse from God. They were strangers; they were black; they were heathens. They qualified to be slaves on all counts, and the prejudice against them seems to have been widespread in both England and America. ${ }^{38}$

Thus, in the Virginia of the early and mid-seventeenth century those who held power had both an economic need for cheap labor and a moral justification for treating a vulnerable people badly. In this context it is not surprising that the legal decisions made by the powerful men who sat on the court served to legitimize and institutionalize hereditary racial slavery.

\section{The Legal Environment of the Development of Slave Law in Virginia}

The early decision of Whites in Virginia to treat Blacks as property rooted in English racial attitudes, the economic context of Virginia, and the unconstrained nature of judicial power in the colony, led to the development of laws designed to protect the slave owners' rights in their black property. Conciliar justice, swift, arbitrary, and brutal, was instrumental in creating the atmosphere of profound disrespect for individual liberties that 


\section{Ethnic Studies Review Volume 27: 1}

enabled masters to abuse white servants at will and to hold black servants for life. Later, as the need to regulate slavery began to replace the need to impose it, the Virginia legal system came to protect this particular type of property in much the same way all property was protected in England -- though the application of the ordinary concepts of the common law. Thus, two different aspects of the English legal tradition were drawn on in the creation of slavery as a legal institution.

The development of slave law in Virginia was contemporaneous with the development of Virginia's legal system itself. The 1606 and 1609 charters of the Virginia Company both contain vague guarantees of traditional English rights for the colonists, but are entirely unclear as to the practical meaning of this guarantee. The 1606 Charter, for example, states only that inhabitants of Virginia ". . . shall have and enjoy all liberties, franchises, and immunities .... as if they had been abiding and borne within this our realm of Englande . . . 39 The supplemental instructions do little to make this any clearer. They order the colonial council to govern "as neare to the Common Law [of] England and the equity thereof as may be." 40

Nor do the English legal commentators and theorists provide any elucidation of the practical relationship between English legal doctrine and colonial justice. Blackstone includes a very brief discussion of these issues in his Commentaries, concluding only that the general claim that all English laws accompany colonists to an uninhabited country "must be understood with very many and very great restrictions." He does not, however, say what those restrictions might be. Otherwise, there is nearly total silence from the English legal community. No real theory of colonial jurisprudence was articulated. ${ }^{41}$

In the absence of direction from home, then, colonial jurisprudence evolved on its own. The dominant explanation of that evolution has been that the language of the Charters transferred to Virginia the general legal framework of the mother country - its traditional legal customs and practices - rather than the entire developed body of common law principles. Aspects of this system were then changed, replaced or dropped under the influence of Virginia's economic, social, and political environments. A similar transformation took place in the devel- 
opment of a uniquely American body of substantive law. ${ }^{42}$

The transfer of English law to Virginia, in this view, was a process of adaptation to meet colonial needs. This adaptation took place in a variety of ways. Sometimes change was wrought by deliberate dissent from English legal customs, sometimes by an imperfect understanding of those customs, and sometimes by a lack of any applicable English precedents. It is acknowledged that such a transition would have been halting and painful, but it is seen in a larger way as a logical, coherent, and essentially orderly process that gradually brought the principles of the common law to the colonies basically intact. ${ }^{43}$

This view, however, ignores or at least downplays the actual operation of the early Virginia legal system, which bears almost no resemblance to its counterpart in England, and fails to acknowledge its powerful relationship with another, less benign, type of English justice that had its roots in the social disorder and official suppression of the lower classes in sixteenth-century England. The social, political, and economic turmoil of Tudor England was met with increasingly severe treatment for the lower classes who, displaced by the convulsions, were seen as violators of public order, their dislocations proof of moral failure rather than illustrations of the deterioration of the social fabric. Greater authority was given to the courts and far-reaching poor laws and measures against vagrancy were enacted, using compulsory labor, galley servitude, and colonization as ways to deal with disorder. ${ }^{4}$

Tudor methods of suppressing dissent were harshest in the areas farthest from London. In the northern and western hinterlands and on the Irish frontier, local nobles were placed in control of governing councils which had responsibility for enforcing justice in these areas. While these bodies were theoretically bound, to one degree or another by the protections of the common law, in practice they were free to ignore those restraints and to issue whatever summary justice they chose as long as they kept the unruly poor under control. Common law procedures designed to protect individual rights and liberties were meaningless. 45

In Virginia, an analogous situation existed. Whereas the Charters were vague about common law protections for the 


\section{Ethnic Studies Review Volume 27: 1}

colonists, they were quite specific in setting up a ruling council, which functioned as a judicial body just as powerful as the other conciliar courts. The council came into existence with the creation of the colony. The Company of London appointed the members of the council. The general court was the colony's highest judicial body; however, for a number of years, it shared jurisdiction concurrently with the legislature. Criminal cases were tried in whichever body convened first. After 1640, the civil jurisdiction of the assembly was limited primarily to appellate cases. ${ }^{46}$ And, in practice, the Council in Virginia was just as unconcerned with common law procedures as were authorities in England. The common law was not the only law in England, and on the frontiers summary justice was the rule. ${ }^{47}$

Examples of the unconstrained nature of judicial power in early Virginia are abundant and are found in every period from the First Charter through the Third and continuing well after Virginia became a Royal Colony. The reported cases demonstrate a complete lack of concern on the part of the court for individual liberties, procedural protections, or even jurisdiction. Clearly, the agenda of the Council acting as court was to control the potentially unruly lower classes who made up Virginia's laboring population and to guard the power and wealth of its members.

For example, in May, 1624, one Richard Barnes was accused of uttering "base and detracting" speeches against the governor. The court ordered that he "be disarmed, and have his armes broken and his tongue bored through with an awl. [He] shall pass through a guard of 40 men and shalbe butted by every one of them, and at the head of the troope kicked downe and footed out of the fort: that he shalbe banished out of James Cittye and the Iland, that he shall not be capable of any priviledge of freedome of the countrye, and that (before he goe out of the Iland) he shall put in suretyes of 200 bond for the good behavior." 48

At about the same time, members of the Council became aware of grumblings of discontent against the execution of a shipmaster named Richard Cornish for sodomy. Edward Nevell encountered Cornish's brother on a ship off the coast of Canada and voiced his dissatisfaction with the execution. The Council 
learned of the conversation and charged Mr. Newell with blasphemy. For this offense, over which it certainly lacked jurisdiction, the court sentenced Nevell to "stand on the pillory with a paper one his head shewinge the cause of his offence . . . and to loose both his Ears and to serve the Colony for A yeere, And forever to be incapable to be a ffree man of the countrey." 49

In handing out punishments the court did not hesitate to consider the economic advantage of its powerful members. For example, his criticism of the same execution got Thomas Hatch, a servant whose seven-year term was almost finished, a sentence of a whipping and the loss of one ear. The court also ordered that "his service to Sir George Yeardley for seven yeeres shal begain from the present dye." 50 When Luke Eden sought payment of a debt owed him by Sir Edwin Sandys, he wound up "laid neck and heels" for his "unreverent speche" and in debt to Sandys for two hundred pounds of tobacco. 51

The only justice in Virginia, then, was the unmitigated authority of the Council, which was not especially concerned with protecting anyone's traditional rights, much less those of the common laborers and servants who came before them. The context of the development of the early law of slavery was thus deeply authoritarian. In this atmosphere of unconstrained legal authority the councillors made their decisions concerning the customary practices of slavery. Lack of respect for the rights of the lower classes, cultural contempt for Blacks, and economic self-interest combined to produce case law, and ultimately legislation, that reinforced the institution of slavery at every turn, lack of English legal precedents not withstanding.

A clear example of the operation of this process is found in the development of the legal rule that the status of a black child descends from its mother.52 Many interpreters have explained this rule by arguing that as cases concerning the status of children with black mothers and white fathers came before the court, the court first looked to English law for precedents. Although the general rule of English law of status is that status is derived from the father, there is no category of "slave" to be found in that body of law, and, rather than apply the general principle to a slightly different circumstance, this argument contends that the jurists on the Virginia council turned to continen- 


\section{Ethnic Studies Review Volume 27: 1}

tal civil law codes, which addressed slavery directly. Here they supposedly found an answer to the legal issue raised by miscegenation that was directly on point: the doctrine of partus sequiter ventrum -that the status of a child with mixed slave and free parentage follows the status of the mother. This, then, was the law that was eventually adopted in Virginia, in 1662, after the initial confusion over the issue. The statute's wording that "Children got by an Englishman upon a Negro woman shall be bond or free according to condition of the mother, ..." failed to address the reality that black men fathered children with white Christian women. In fact, the child of a white woman and black male became a servant or slave according to the status of father. 53

It is extremely unlikely, however, that the source of partus sequiter ventrum is the continent. Its true source is no legal doctrine at all but rather is the same logic of domination by force that guided all of the court's decision-making in this early period. Neither the councillors nor, later, the Burgesses were equipped to make their way through arcane English status law or complex foreign civil codes, even if they had access to then, which they probably did not. ${ }^{54}$ The real legal problem was that the familiar legal doctrine that status derives from the father would not work to maintain a growing system of racially based chattel slavery.

The logic of slavery required that the slave be reified, treated as a thing, not as a person, and the decision to make slavery descend from the mother makes the most sense when seen as a matter of determining the ownership of something rather than the status of someone. Given the social, racial, and economic context of seventeenth-century Virginia, once the custom of holding Blacks as slaves had become established, it must have seemed natural to the wealthy, powerful men who controlled the colony and the court, to conceptualize a slave woman as a piece of livestock. And English law had clear rules about livestock. If a litter of pigs belongs to the owner of the sow, then obviously a black woman's child belongs to its mother's master. That this outcome would also increase their personal wealth as well as avoid complicated and unpleasant personal entanglements could not have escaped the decision-makers' notice either. 
Thus, once it was established that concern for the property rights of slaveholders was the key factor in determining legal doctrine, there were simple, well-known rules available to protect and preserve those interests. English law contained in the common law one of the most developed and effective schemes for the protection of property ever devised, and there was absolutely nothing to prevent the court from applying it to Blacks. 55

The legal institutionalization of slavery, then, was not an aberration or an exception to the general pattern of early legal development in Virginia. Once racism and greed had impelled the practice, the unrestrained conciliar judicial system, with its utter disregard for the individual liberties of the lower classes, permitted it to continue, and the common law provided the means to regulate it and to close the loopholes left by custom. English legal tradition thus forms the basis of both the later, more developed law of slavery and the society created by and for white Virginians. The institution that favors freedom in one context can also be the means of the continued oppression of an entire ethnic group. The foundation stone of liberty can be used as the instrument of complete loss of liberty. The English tradition of representative government, a bulwark against tyranny, enabled the Virginia legislature, full of slaveholders, to complete the job begun by the early court and completely strip Blacks of their legal humanity. Between 1680 and 1682 the legislature completed the task, enacting the first major slave codes. It not only synthesized the judicial rulings and statutory provisions of the previous four decades but also introduced others incorporating some of the strict customs and traditions that had developed to control Virginia's indentured servants. Had it chosen to do so, Virginia could have referenced developments in England. Two years before the centennial of the 1569 Cartwright56 decision, in which it held that slavery was inconsistent with English traditions, the English court, in Butts v. Penny, 57 ruled that black slavery was legal within England. 


\section{NOTES}

1.. See George Stroud, A Sketch of the Laws Relating to Slavery in the Several States of the United States of America(Philadelphia, 1827, reprinted 1968) and William Goodell, The American Slave Code in Theory and Practice (Philadelphia, 1853) for early illustrations of this thesis. Later expressions of this view can be found in William $M$. Wiecek, "The Statutory Law of Slavery and Race in the Thirteen Mainland Colonies of British America," William and Mary Quarterly, 34 (1977): 258-280 and Warren M. Billings, "The Cases of Fernando and Elizabeth Key: A Note on the Status of Blacks in SeventeenthCentury Virginia," William and Mary Quarterly, 30 (1973): 467-474; Oscar and Mary F. Handlin also take this position in "Origin of the Southern Labor System," William and Mary Quarterly, 7 (1950): 199222.

2 David Brion Davis, The Problem of Slavery in Western Culture (Ithaca, New York, 1966), 32.

3 William Waller Hening, ed., The Statutes at Large; Being a Collection of All the Laws of Virginia, from the First Session of the Legislature in the Year 1619 (13 vols.; Richmond, 1809-23) I, 257, 411, 471 and 538-39 and Helen Tunnicliff Catterall, ed., Judicial Cases Concerning American Slavery and the Negro I, (Washington, D.C., 1926), 76.

4 See Alden T. Vaughan, "The Origins Debate: Slavery and Racism in Seventeenth-Century Virginia," The Virginia Magazine of History and Biography 97 (July 1989): 311-354; Susie M. Ames, Studies of the Virginia Eastern Shore in the Seventeenth Century (Richmond, 1940), 100-106 and Wesley Frank Craven, "The Southern Colonies in the Seventeenth Century, 1607-1689" in Wendell H. Stephenson and E. Merton Coulter, eds., A History of the South I, (Baton Rouge, 1949), 217-219.

5 T.H. Breen and Stephen Innes, "Myne Own Ground": Race and Freedom on Virginia's Eastern Shore, 1640-1676 (New York, 1980) provides a comprehensive examination of the Anthony Johnson case. See also Ross M. Kimmel, "Free Blacks in Seventeenth-Century Maryland," Maryland Historical Magazine 71 (1976): 22-25 and James H. Brewer, "Negro Property Owners in Seventeenth Century Virginia," William and Mary Quarterly, 12 (1955): 576-578.

6 A. Leon Higginbotham, Jr., Shades of Freedom: Racial Politics and Presumptions of the American Legal Process (New York, 1996), 19. 
7 H.R. Mcllwaine, ed., Minutes of the Council and General Court of Colonial Virginia, 1622-1632, 1670-1676, (Richmond, Virginia, 1924) 72.

8 Ibid., 73.

9 Ibid., 477; Hening, Statutes, I, 146.

10 Higginbotham, Shades of Freedom, 20-22; Mcllwaine, Minutes, 552.

11 Ibid., 226.

12 Catterall, Judicial Cases, I, 77.

13 Ibid., 30.

14 Mcllwaine, Minutes, 477; Catterall, Judicial Cases, I, 58; "Virginia Council and General Court Records, 1640-1641," Virginia Magazine of History and Biography 11 (January, 1904): 281.

15 Stephen Botein, Early American Law and Society (New York, 1983), 13.

16 Cited in Thomas D. Morris, "The Problem of the 'Sources' of Southern Slave Law," American Journal of Legal History 32 (1988): 110.

17 Warren M. Billings, ed., The Old Dominion in the Seventh Century: A Documentary History of Virginia, 1606-1689 (Chapel Hill, North Carolina, 1975), 165-69, and "The Cases of Fernando and Elizabeth Key," 469-478.

18 Hening, Statutes, II, 170.

19 Higginbotham, Shades of Freedom, 19-20.

20 Alden T. Vaughan, "Blacks in Virginia: A Note on the First Decade," William and Mary Quarterly, 34 (1972): 478.

21 Joseph Boskin, Into Slavery: Racial Decisions in the Virginia Colony (Philadelphia, 1976), 41.

22 Catterall, Judicial Cases, I, 58. 


\section{Ethnic Studies Review Volume 27: 1}

23 A. Leon Higginbotham, Jr. In the Matter of Color: Race and the American Legal Process; The Colonial Period. (New York, 1978), 36.

24 Hening, Statutes, II, 260.

25 Higginbotham, In the Matter of Color, 36.

26 See Evsey D. Domar, "The Causes of Slavery or Serfdom: A Hypothesis," Journal of Economic History 30 (1970): 18-32; Robert Evans, "Some Notes on Coerced Labor," Ibid., 861-866; Stanley L. Engerman, "Some Considerations Relating to Property Rights in Man," Ibid., 33 (1973); 43-65 and Edmund S. Morgan, "The First American Boom: Virginia 1618 to 1630," William and Mary Quarterly, 28 (1971): 169-198 for discussions on the relation between free land and coerced labor.

27 Morgan, "First Boom," 175-176.

28 Ibid., 197-98; Mcllwaine, Minutes, 82.

29 Mcllwaine, Minutes, 22-24.

30 Morgan, "First Boom," 170-76.

31 Robert William Fogel, Without Consent or Contract: The Rise and Fall of American Slavery (New York, 1989), 35.

32 Robert McColley, "Slavery in Virginia, 1619-1660: A Reexamination," in Robert H. Abzug and Stephen Maizlich, eds., New Perspectives on Race and Slavery in America: Essays in Honor of Kenneth M. Stampp (Lexington, Ky., 1986), 18-19.

33 On the English adoption of black slavery in the Caribbean see Carl Bridenbaugh, No Peace Beyond the Line: The English in the Caribbean (New York, 1972) and Virginia Bernhard, "Beyond the Chesapeake: The Contrasting Status of Blacks in Bermuda, 1616-1663," Journal of Southern History 54 (November, 1988): 545-64. On the peripheral involvement of Virginia in the slave trade see James A. Rawley, The Transatlantic Slave Trade (New York, 1981). And on the role of the Dutch see Cornelius C. Goslinga, The Dutch in the Caribbean and on the Wild Coast, 1580-1680 (Gainesville, 1971).

34 Hening, Statutes, I, 540. 
35 McColley, "Slavery in Virginia," 18.

36 Susan Myra Kingsbury, ed., The Records of the Virginia Company of London III, (Washington, D.C., 1933), 243. See also W.F. Craven, "Twenty Negroes to Jamestown in 1619?," Virginia Quarterly Review, 47 (1971), 416-21.

37 Alden T. Vaughan, "Blacks in Virginia," 469-78, and Annie Lash Jester and Martha Woodruff Hiden, eds., Adventures of Purse and Person: Virginia 1607-1625 (Princeton, 1956), 5-69.

38 Winthrop D. Jordan, White Over Black: American Attitudes Toward the Negro, 1550-1812 (Chapel Hill, 1968), Chapter 1, James Walvin, Black and White: The Negro and English Society, 1555-1945 (London, 1973), chapters I-III, and Anthony Gerard Barthelemy, Black Face, Maligned Race: The Representation of Blacks in English Drama from Shakespeare to Southern (Baton Rouge, 1987); Also see Edith R. Sanders, "The Hamitic Hypothesis, Its Origin and Functions in Time Perspective," The Journal of African History X (1969): 521-532.

39 The 1606 Charter can be found in P.L. Barbour, ed., The Jamestown Voyages Under the First Charter, 1606-1609, 2 vols., Hakluyt Society, (Cambridge, 1969), I. 31. Both the 1609 and the 1606 Charters are in S.M. Bemiss, ed., The Three Charters of the Virginia Company of London, with Seven Related Documents, 1606-1621 (Williamsburg, Va., 1957).

40 Barbour, Jamestown Voyages, I, 35-36.

41 Sir William Blackstone, Commentaries on the Laws of England I, 103 (Philadelphia, 177-72). Wilcomb Washburn, "Law and Authority in Colonial Virginia," in George Billias, ed., Law and Authority in Colonial America (Barre, Mass., 1965).

42 See Warren M. Billings, "The Transfer of English Law to Virginia, 1606-50," in K.R. Andrews, N.P. Canny, and P.E.H. Hair, eds., The Westward Enterprise: English Activities in Ireland, the Atlantic, and America, 1480-1650 (Detroit, 1979), 215-244.

\section{Ibid.}

This argument is advanced by David T. Konig in "'Dale's Laws' and the Non-Common Law Origin of Criminal Justice in Virginia," American 


\section{Ethnic Studies Review Volume 27: 1}

Journal of Legal History 26 (1982): 354, in the context of the development of criminal law in seventeenth-century Virginia. His conclusions appear equally applicable to the development of the law of slavery, and 1 make use of them heavily in the following discussion.

45 Ibid., 357-63.

46 Higginbotham, In the Matter of Color, 23.

47 Ibid., 363-75.

48 Mcllwaine, Minutes, 14.

49 Ibid., 85.

50 Ibid., 93.

51 Ibid., 57.

52 Hening, Statutes, II, 170.

53 See Morris, "Villeinage,"108-21; Hening, Statutes, III, 86-88; and, Higginbotham, Shades of Freedom, 32-36.

54 See Warren M. Billings, "Law and Culture in the Colonial Chesapeake Area," Journal of Southern Studies 17 (1978): 337-39 for a discussion of the law books available in seventeenth-century Virginia.

55 See J.H. Baker, "Property in Chattels," Selden Society 94 (1978): 205-221 and An Introduction to English Legal History 2d ed., London, 1979) for an overview of how the common law grants near-absolute power to chattel owners.

56 Higginbotham, In the Matter of Color, 321

57 Ibid. 